ISSN 1112-9867

\title{
SPATIAL ASSESSMENT ON AMBIENT AIR QUALITY STATUS: A CASE STUDY IN KLANG, SELANGOR
}

\author{
N. Z. Shafii ${ }^{1}$, A. S. M. Saudi ${ }^{1, *}$, M. Mahmud ${ }^{1}$ and Z. I. Rizman ${ }^{2}$ \\ ${ }^{1}$ Department of Environmental Healthcare, Institute of Medical Science and Technology, \\ Universiti Kuala Lumpur, Kajang, Selangor, Malaysia \\ ${ }^{2}$ Faculty of Electrical Engineering, Universiti Teknologi MARA, 23000 Dungun, Terengganu, \\ Malaysia
}

Published online: 05 October 2017

\begin{abstract}
Klang as the center of economic and industrial zone in Malaysia has been exposed to poor air quality condition over the years. This study was conducted to evaluate the spatial variation pattern of air quality status in Klang, Selangor by using a four years (2010-2013) secondary database from the Malaysian Department of Environment (DOE). The finding shows that carbon monoxide $(\mathrm{CO})$ had a strong correlation with nitrogen dioxide $\left(\mathrm{NO}_{2}\right)(\mathrm{r}=0.76, \mathrm{p}<$ 0.001), while Air Pollutant Index (API) had moderate correlation with particulate matter $\left(\mathrm{PM}_{10}\right)(\mathrm{r}=0.64, \mathrm{p}<0.001)$. Principal Component Analysis $(\mathrm{PCA})$ indicates that the most significant air pollutants were $\mathrm{NO}_{2}, \mathrm{CO}$ and $\mathrm{PM}_{10}$. Statistical Process Control (SPC) reveals that several $\mathrm{PM}_{10}$ data beyond the limitations of SPC and the national guidelines. This study shows that active collaboration among all relevant environmental departments and agencies should be implemented for the effective management of air quality.
\end{abstract}

Keywords: air quality; correlation; principal component analysis; statistical process control.

Author Correspondence, e-mail: ahmadshakir@unikl.edu.my

doi: http://dx.doi.org/10.4314/jfas.v9i4s.58 


\section{INTRODUCTION}

\subsection{Introduction}

Air pollution currently becomes one of the crucial environmental issues worldwide. The main sources of air pollution in Malaysia are mobile sources, stationary sources and open burning sources [1]. Klang is known as the main hub for industrial and business activities as well as home to the largest and busiest port in Malaysia, Port Klang [2]. Over the last few years, Klang recorded a number of unhealthy air quality status and haze episodes [3]. The most challenge in managing of air quality is the effort in controlling the point and non-point sources of air pollutants. Chemometric technique is proved to be a functional tool to develop the most suitable plans in managing air monitoring network [4]. However, environmental studies using chemometric techniques are very limited in Malaysia. Therefore, this study was aimed to evaluate the spatial variation pattern of the air quality status in Klang, Selangor.

\subsection{Air Quality Status in Klang, Selangor}

A comparison study of ambient air pollutants with the Recommended Malaysia Air Quality Guidelines (RMAQG) shown all pollutants in Klang were within the recommended standard. However, it stated that $\mathrm{PM}_{10}$ concentration was the highest among other pollutants as Klang [2]. This study had been supported by other studies which indicated that $\mathrm{PM}_{10}$ was the most significant pollutant which had been influenced the API values in Klang [4-6]. Besides that, the $\mathrm{PM}_{10}$ value in Klang had been increased over the years. It was reported that the numbers of days with $\mathrm{PM}_{10}$ concentration more than $100 \mu \mathrm{g} / \mathrm{m}^{3}$ increased from 14 days in 2007, followed by 37 days in 2008, 39 days in 2009 and the highest was 41 days in 2011 [2]. This finding was associated with the haze episodes in 2009 and 2011 that were influenced by the south-west monsoon, which normally in hot and dry season [2-3].

\section{MATERIALS AND METHODS}

\subsection{Study Area}

This analytical study was based at Klang, Selangor. The sampling station used in this study is namely as the Klang air monitoring station (Latitude: $3^{\circ} 00^{\prime} 62^{\prime \prime} \mathrm{N}$; Longitude: $101^{\circ} 24^{\prime} 48^{\prime \prime}$ E). This station is located at Raja Zarina Girls School, Port Klang, Selangor and surrounded by residential and industrial area and next to the major road of Port Klang. This area was 
selected to give a general representation of the air quality status in Klang.

\subsection{Data Collection}

Secondary air quality data was obtained from the Air Quality Division of DOE. The data was collected and monitored by the authorised agency, Alam Sekitar Malaysia Sdn. Bhd. (ASMA) for the DOE. A four-year database (2010-2013) was used in this study and it contained five major air pollutants include carbon monoxide $(\mathrm{CO})$, nitrogen dioxide $\left(\mathrm{NO}_{2}\right)$, sulphur dioxide $\left(\mathrm{SO}_{2}\right)$, ozone $\left(\mathrm{O}_{3}\right)$ and particulate matter with diameter less than 10 microns $\left(\mathrm{PM}_{10}\right)$. In addition, meteorological parameters such as wind speed, wind direction, ambient temperature and relative humidity as well as Air Pollutant Index (API) values were also used in this study.

\subsection{Data Analysis}

In this study, chemometrics technique was carried out for the statistical analysis of database. The correlation test was used to determine the significant relationship between variables and the strength of the relationship. Principal Component Analysis (PCA) was applied to analyze the most significant air pollutants that contributed as the sources of air pollution variation in Klang. Monitoring and evaluating of air pollutants patterns was done using time series analysis that based on Statistical Process Control (SPC) in order to determine the air quality status in Klang.

\section{RESULTS AND DISCUSSION}

\subsection{The Association between Air Pollutants, Meteorological Variables and API in Klang, Selangor}

The Spearman's correlation test was applied as the non-parametric test to determine the relationship of air quality data in Klang. Table 1 showed the correlation coefficients, $r$, between air pollutant parameters, meteorological variables and the API. Correlation analysis revealed that all variables had significant relationships except for API as it had no correlation with wind speed $(r=0.01, p=0.26)$ and with ambient temperature $(r=0.00, p=0.78)$.

All pollutants in this study had significant positive correlations with each other. CO had a positive strong correlation with $\mathrm{NO}_{2}(\mathrm{r}=0.76, \mathrm{p}<0.0001) . \mathrm{PM}_{10}$ had a significantly moderate correlation with $\mathrm{CO}(\mathrm{r}=0.74, \mathrm{p}<0.0001)$ and with $\mathrm{NO}_{2}(\mathrm{r}=0.64, \mathrm{p}<0.0001)$. These findings were consistent with [2] who stated high correlation of $\mathrm{CO}$ and $\mathrm{PM}_{10}$. For 
meteorological variables, relative humidity had a strong negative correlation with ambient temperature $(\mathrm{r}=-0.78, \mathrm{p}<0.001)$. In addition, API values had a significantly positive moderate correlation with $\mathrm{PM}_{10}(\mathrm{r}=0.64, \mathrm{p}<0.0001)$ and positive fair correlation with $\mathrm{O}_{3}(\mathrm{r}$ $=0.49, \mathrm{p}<0.0001), \mathrm{CO}(\mathrm{r}=0.41, \mathrm{p}<0.0001)$ and $\mathrm{NO}_{2}(\mathrm{r}=0.40, \mathrm{p}<0.0001)$.

Table 1. Spearman's correlation coefficient (r) between all variables for 4 years (2010-2013)

\begin{tabular}{ccccccccccc}
\hline Variables & $\mathbf{W S}$ & $\mathbf{W D}$ & $\mathbf{T}$ & $\mathbf{H}$ & $\mathbf{S O}_{2}$ & $\mathbf{N O}$ & $\mathbf{O}_{3}$ & $\mathbf{C O}$ & $\mathbf{P M} \mathbf{1 0}_{\mathbf{1 0}}$ & $\mathbf{A P I}$ \\
\hline $\mathrm{WS}$ & 1 & $0.17^{*}$ & $0.59^{*}$ & $-0.58^{*}$ & $0.04^{*}$ & $-0.15^{*}$ & $0.29^{*}$ & $-0.23^{*}$ & $-0.14^{*}$ & 0.01 \\
$\mathrm{WD}$ & $0.17^{*}$ & 1 & $0.16^{*}$ & $-0.18^{*}$ & $0.07^{*}$ & $-0.05^{*}$ & $0.03^{*}$ & $-0.08^{*}$ & $-0.09^{*}$ & $-0.08^{*}$ \\
$\mathrm{~T}$ & $0.59^{*}$ & $0.16^{*}$ & 1 & $-0.78^{*}$ & $-0.10^{*}$ & $-0.28^{*}$ & $0.08^{*}$ & $-0.33^{*}$ & $-0.20^{*}$ & 0.00 \\
$\mathrm{H}$ & $-0.58^{*}$ & $-0.18^{*}$ & $-0.78^{*}$ & 1 & $-0.06^{*}$ & $0.15^{*}$ & $-0.22^{*}$ & $0.19^{*}$ & $0.05^{*}$ & $-0.08^{*}$ \\
$\mathrm{SO}_{2}$ & $0.04^{*}$ & $0.07^{*}$ & $-0.10^{*}$ & $-0.06^{*}$ & 1 & $0.50^{*}$ & $0.43^{*}$ & $0.46^{*}$ & $0.46^{*}$ & $0.25^{*}$ \\
$\mathrm{NO}_{2}$ & $-0.15^{*}$ & $-0.05^{*}$ & $-0.28^{*}$ & $0.15^{*}$ & $0.50^{*}$ & 1 & $0.44^{*}$ & $0.76^{*}$ & $0.64^{*}$ & $0.40^{*}$ \\
$\mathrm{O}_{3}$ & $0.29^{*}$ & $0.03^{*}$ & $0.08^{*}$ & $-0.22^{*}$ & $0.43^{*}$ & $0.44^{*}$ & 1 & $0.34^{*}$ & $0.42^{*}$ & $0.49^{*}$ \\
$\mathrm{CO}$ & $-0.23^{*}$ & $-0.08^{*}$ & $-0.33^{*}$ & $0.19^{*}$ & $0.46^{*}$ & $0.76^{*}$ & $0.34^{*}$ & 1 & $0.74^{*}$ & $0.41^{*}$ \\
$\mathrm{PM}_{10}$ & $-0.14^{*}$ & $-0.09^{*}$ & $-0.20^{*}$ & $0.05^{*}$ & $0.46^{*}$ & $0.64^{*}$ & $0.42^{*}$ & $0.74^{*}$ & 1 & $0.64^{*}$ \\
$\mathrm{API}$ & 0.01 & $-0.08^{*}$ & 0.00 & $-0.08^{*}$ & $0.25^{*}$ & $0.40^{*}$ & $0.49^{*}$ & $0.41^{*}$ & $0.64^{*}$ & 1 \\
\hline
\end{tabular}

Note: $*=\mathrm{p}<0.05 ;$ Bold $=\mathrm{r} \geq 0.50 ; \mathrm{WS}=$ Wind speed, $\mathrm{WD}=$ Wind direction, $\mathrm{T}=$ Ambient temperature, $\mathrm{H}=$ Relative humidity

The significant relationship between air pollutants was caused by the traffic-oriented of Klang station, as it was located next to main road to Port Klang. $\mathrm{CO}$ and $\mathrm{NO}_{2}$ had a strong relationship as both pollutants were from the emission of motor vehicles [7-8]. Moreover, the concentration of air pollutants was determined by differences in topography, climatic conditions and economic activities [9]. The relationship between API and $\mathrm{PM}_{10}$ shown that as the concentration of $\mathrm{PM}_{10}$ increased, the API level was increased as indicated in the previous studies [8-10]. Thus, this study found that a significant association among air pollutants in Klang need to be further analyzed by PCA and SPC. 


\subsection{Spatial Identification of the Most Significant Air Pollutants in Klang, Selangor}

Further analysis was carried out in this study in order to analyze the major air pollutants that contributed as the sources of air pollution variation in Klang. Therefore, principal component analysis (PCA) was applied on the database. Analysis showed that out of nine principal components (PCs), there were only two PCs with an eigenvalue greater than one $(>1.0)$ that accounted for $63.34 \%$ of the total variance in the database. Thus, these two PCs were selected for varimax rotation process. PCs with eigenvalues less than one $(<1.0)$ were neglected due to the redundancy with main factors [4]. The scree plot diagram (Fig. 1) was used to determine the cut-off point of the strong factors selected for interpretation.

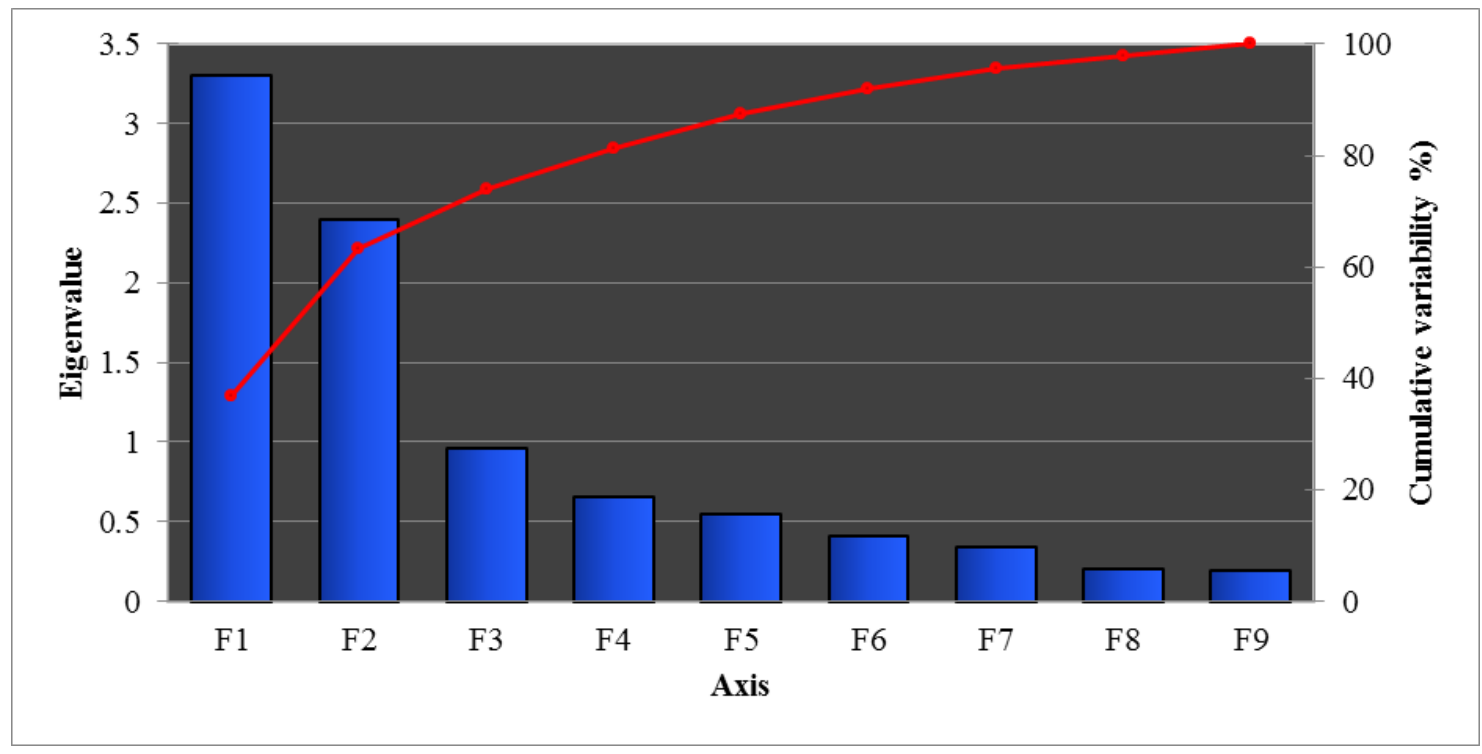

Fig.1. Scree plots for PCA

After varimax rotation, two varifactors (VFs) or factor loadings were obtained which represented the $63.34 \%$ of the cumulative variance of the data. Table 2 highlighted the findings of factor loadings after varimax rotation. The total variance in the first factor loading (VF1) was about $34.98 \%$ with strong positive factor loadings for $\mathrm{NO}_{2}(0.85), \mathrm{CO}(0.84)$ and $\mathrm{PM}_{10}(0.83)$. Moreover, the second factor loading (VF2) accounted for $28.36 \%$ of the total variance with two strong positive factor loadings on ambient temperature (0.85) and wind speed (0.82) and also a strong negative factor loading on relative humidity (-0.88). In this study, only factor loadings greater than $0.75(>0.75)$ were selected for interpretation as these values were considered as stable and strong loadings. The plot diagram for factor loading after varimax rotation was illustrated in Fig. 2. 
Besides that, this study also revealed that the Cronbach's alpha for VF1 and VF2 was 0.84 and -0.59 respectively. Cronbach's alpha was computed to determine the reliability or the strength of consistency of variables. Thus, only variables with strong factor loadings in VF1 were selected for further analysis as it had a good consistency. The variables include $\mathrm{NO}_{2}, \mathrm{CO}$ and $\mathrm{PM}_{10}$. These variables were classified as the most potential contributors of air pollutants in Klang, Selangor.

Table 2. Factor loadings after varimax rotation

\begin{tabular}{ccc}
\hline Variable & VF1 & VF2 \\
\hline $\mathrm{SO}_{2}$ & 0.720 & 0.121 \\
$\mathrm{NO}_{2}$ & 0.854 & -0.165 \\
$\mathrm{O}_{3}$ & 0.661 & 0.381 \\
$\mathrm{CO}$ & 0.846 & -0.259 \\
$\mathrm{PM}_{10}$ & 0.837 & -0.102 \\
Wind speed & -0.038 & 0.822 \\
Wind direction & -0.024 & 0.314 \\
Ambient temperature & -0.215 & 0.856 \\
Relative humidity & 0.017 & -0.883 \\
\hline Eigenvalue & 3.305 & 2.396 \\
Variability (\%) & 34.985 & 28.359 \\
Cumulative (\%) & 34.985 & 63.344 \\
Cronbach's alpha & 0.843 & -0.595 \\
\hline
\end{tabular}

Note: Bold $=$ Factor loading $>0.75$ 


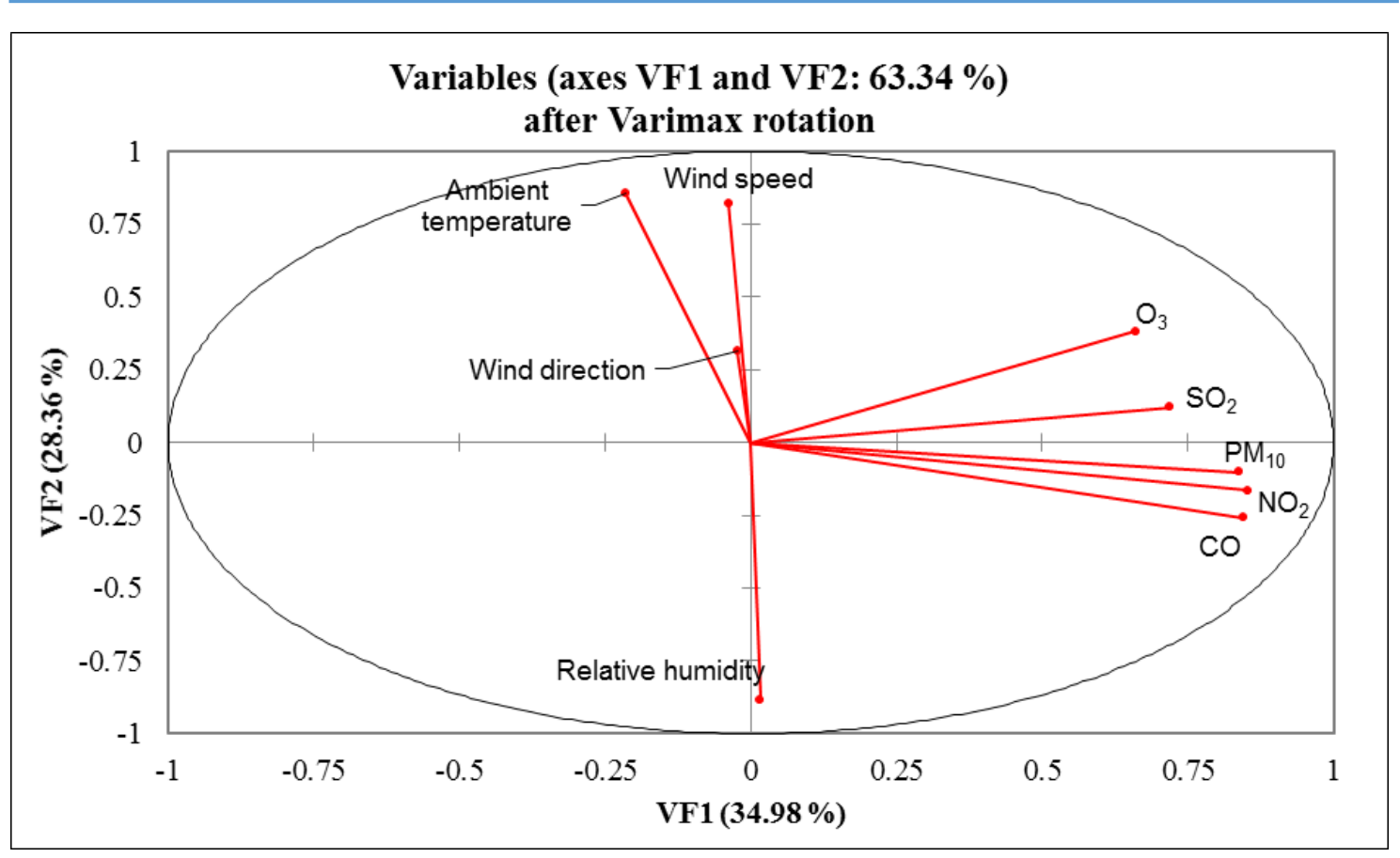

Fig.2. Factor loadings plot after varimax rotation

$\mathrm{NO}_{2}$ emission was attributed to the industrial activities and heavy traffic that surrounded the Klang monitoring station [6]. Harbour and port activities also contributed to this air pollutant [11]. Port Klang as the busiest port in Malaysia might contribute to $\mathrm{NO}_{2}$ emission as it was located approximately 3 kilometers from the monitoring station [12]. The presence of high $\mathrm{CO}$ in Klang was largely due to the incomplete combustion of fossil fuels in industries and motor vehicles [4, 6]. According to [13], the average daily road traffic between Klang to Port Klang had been gradually increased form 46,690 in 2009 to 56,513 in 2013. Moreover, $\mathrm{PM}_{10}$ was potentially came from the industrial emissions, power station activity, heavy construction works, motor vehicle exhaustions, re-suspension of soil dust and open burning activity in the study area [4]. It was also attributed by the transboundary haze pollution due to the forest fires from Indonesia [14-15]. Based on these findings, $\mathrm{NO}_{2}, \mathrm{CO}$ and $\mathrm{PM}_{10}$ were selected for time series analysis.

\subsection{The Patterns of Major Air Pollutants That Influenced the Air Quality Status in Klang, Selangor}

The main three air pollutants, $\mathrm{NO}_{2}, \mathrm{CO}$ and $\mathrm{PM}_{10}$ which were resulting from previous $\mathrm{PCA}$ were further analyzed in this study using time series analysis mainly on statistical process control (SPC) in order to investigate the pattern of major air pollutants in Klang. A control chart 
for each parameter was derived to monitor the real-time air pollutants concentrations time series and to identify the occurrence of any alarming values of pollutants that exceeded the permitted values.

Fig. 3 illustrated the finding of using control chart in monitoring the pattern of $\mathrm{NO}_{2}$ at $\mathrm{Klang}$ (2010-2013). The control limit (CL) value for $\mathrm{NO}_{2}$ was $0.032 \mathrm{ppm}$ with the upper control limit (UCL) and lower control limit (LCL) between $0.039 \mathrm{ppm}$ to $0.025 \mathrm{ppm}$. The highest value of $\mathrm{NO}_{2}$ was $0.13 \mathrm{ppm}$ on $24^{\text {th }}$ August 2011, which mainly due to the high traffic congestion and combustion processes in hot weather around that area [2]. Besides that, electrical utilities and industrial boilers also emitted $\mathrm{NO}_{2}$ as Klang monitoring station was located in close proximity of industrial areas and domestic areas such as residential regions, schools and business sectors [16]. Most of $\mathrm{NO}_{2}$ concentrations for 2010 and 2011 were above the CL value. However, the trend started to change in 2012 and 2013 as the concentrations were predominately below than the $\mathrm{CL}$ value. Even though, there was a fluctuation trend, the overall concentrations of $\mathrm{NO}_{2}$ were under the allowed national standard of RMAQG $(0.170 \mathrm{ppm})$. This indicated that the $\mathrm{NO}_{2}$ trend was very low and stable throughout the four years period.

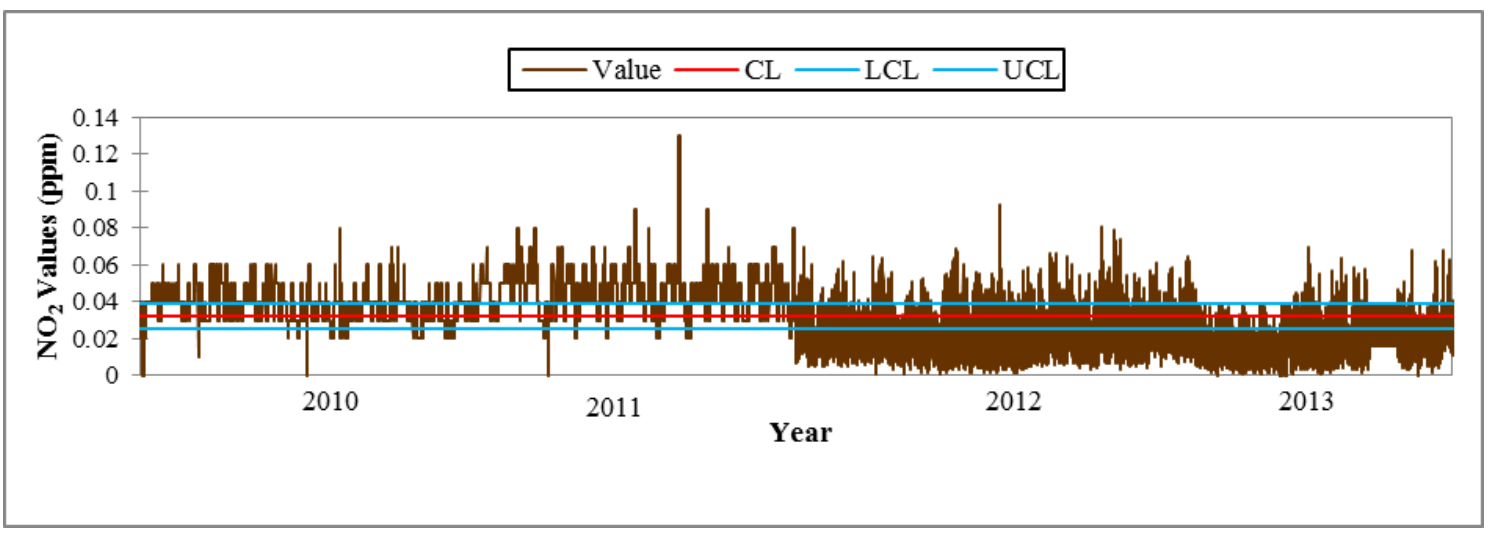

Fig.3. $\mathrm{NO}_{2}$ individual chart

The second contributor air pollutant, $\mathrm{CO}$ shown the values were fluctuated over the 4 years period in Klang (Fig. 4). The chart shown the trend for $\mathrm{CO}$ was oscillated with a few numbers of spikes. The CL for CO was 1.784ppm. While the UCL and the LCL was $2.226 \mathrm{ppm}$ and $1.341 \mathrm{ppm}$ respectively. The highest value recorded at $11.44 \mathrm{ppm}$ on $25^{\text {th }} \mathrm{June} 2013$, followed by $10.810 \mathrm{ppm}$ on $11^{\text {th }}$ August 2012. According to [17], 95\% of CO emission load was mainly from motor vehicles exhaustion. In urban areas, the concentration of $\mathrm{CO}$ would be increased as it 
correlated with the increased demand of transportations [1]. Nevertheless, all CO values recorded in Klang were in compliance to the RMAQG (30.00ppm).

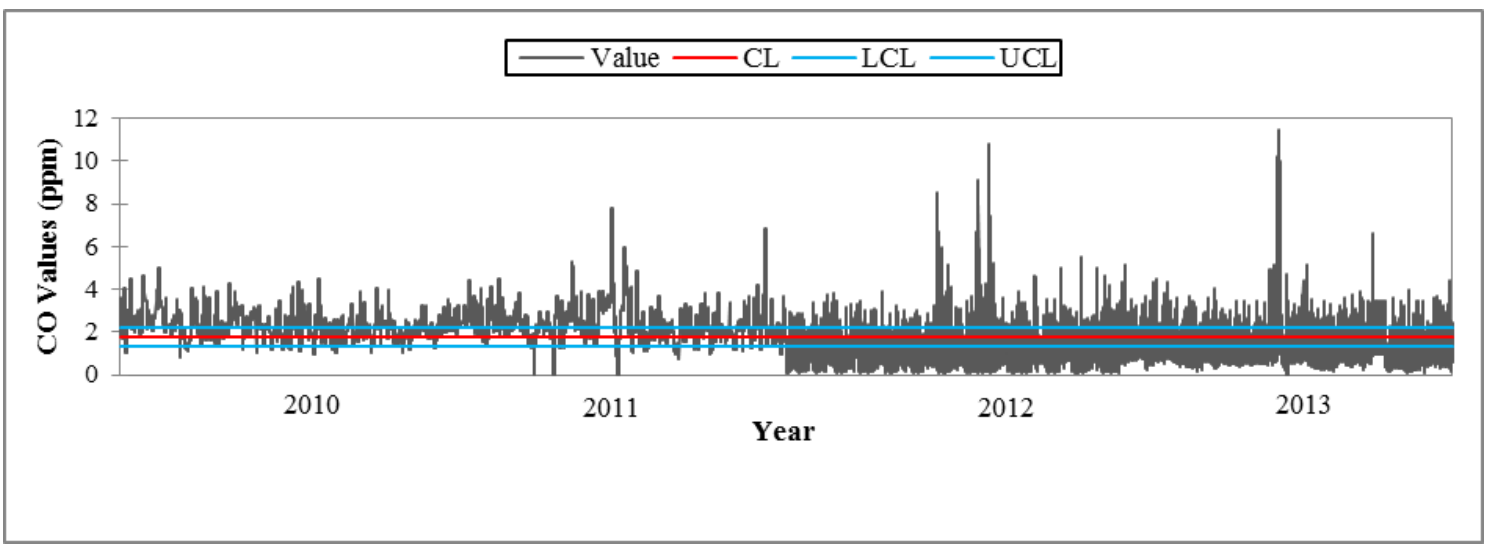

Fig.4. $\mathrm{CO}$ individual chart

Finding in Fig. 5 shown that there were some crucial spikes in the control chart for $\mathrm{PM}_{10}$ concentrations. The CL of $\mathrm{PM}_{10}$ was at $87.308 \mu \mathrm{g} / \mathrm{m}^{3}$ with the UCL at $106.219 \mu \mathrm{g} / \mathrm{m}^{3}$ and the LCL is $68.396 \mu \mathrm{g} / \mathrm{m}^{3}$. There were more than 1075 observations that exceeded the permitted level of RMAQG, $150 \mu \mathrm{g} / \mathrm{m}^{3}$. In addition, 46 observations had $\mathrm{PM}_{10}$ values ranged from $600 \mu \mathrm{g} / \mathrm{m}^{3}$ to $1000 \mu \mathrm{g} / \mathrm{m}^{3}$. Previous study revealed that the concentration of $\mathrm{PM}_{10}$ was significantly higher in Klang as an urban area compared with sub-urban and rural areas $[1,18]$.

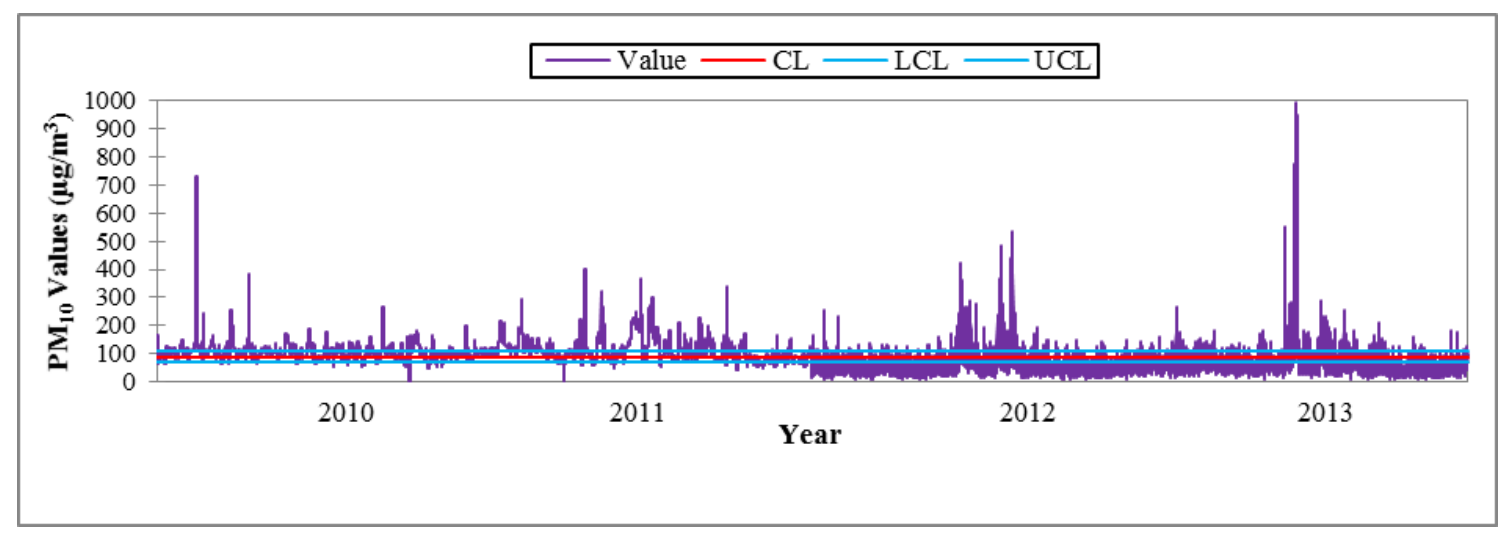

Fig.5. $\mathrm{PM}_{10}$ individual chart

The high concentrations of $\mathrm{PM}_{10}$ in Klang were mostly associated with the transboundary pollution from Indonesia. In mid-June 2013, Klang recorded the highest concentration of $\mathrm{PM}_{10}$ with $995 \mu \mathrm{g} / \mathrm{m}^{3}$ on 23th June 2013 (Fig. 5). This was related to severe haze episodes of transboundary pollution from Sumatra, Indonesia [3]. According to [17], Klang experienced several haze episodes between June to August 2012 due to transboundary pollution of forest 
fires in Sumatra, Indonesia. Another transboundary haze pollution was from April to September 2011 [3]. Surprisingly, between February to April 2010, the high $\mathrm{PM}_{10}$ resulted from peatland fires in Johan Setia, Klang, associated with the hot and dry weather [19]. However, it was significantly improved by the implementation of the Fire Prevention and Peatland Management Programme [19].

The API pattern in Fig. 6 showed that most of API values in Klang were below than 100, which indicated that the air quality in Klang was mostly between good and moderate levels. The CL for API was 59.371 with the UCL and LCL was between 61.372 and 57.371. The CL was slightly higher than the good API, 50. This finding was supported by another study which reported that Klang usually had the low number of good API days and high number of moderate API days [21]. There were about 25 observations of API that were recorded within the range of 400 to 500 . The highest spike of API was 481 (hazardous) on $24^{\text {th }}$ June 2013 , which was reflected to $\mathrm{PM}_{10}$ spikes and $\mathrm{CO}$ spikes within the same time frame. Therefore, this shown that the API pattern in Klang was mostly correlated with $\mathrm{PM}_{10}$ and $\mathrm{CO}$ patterns.

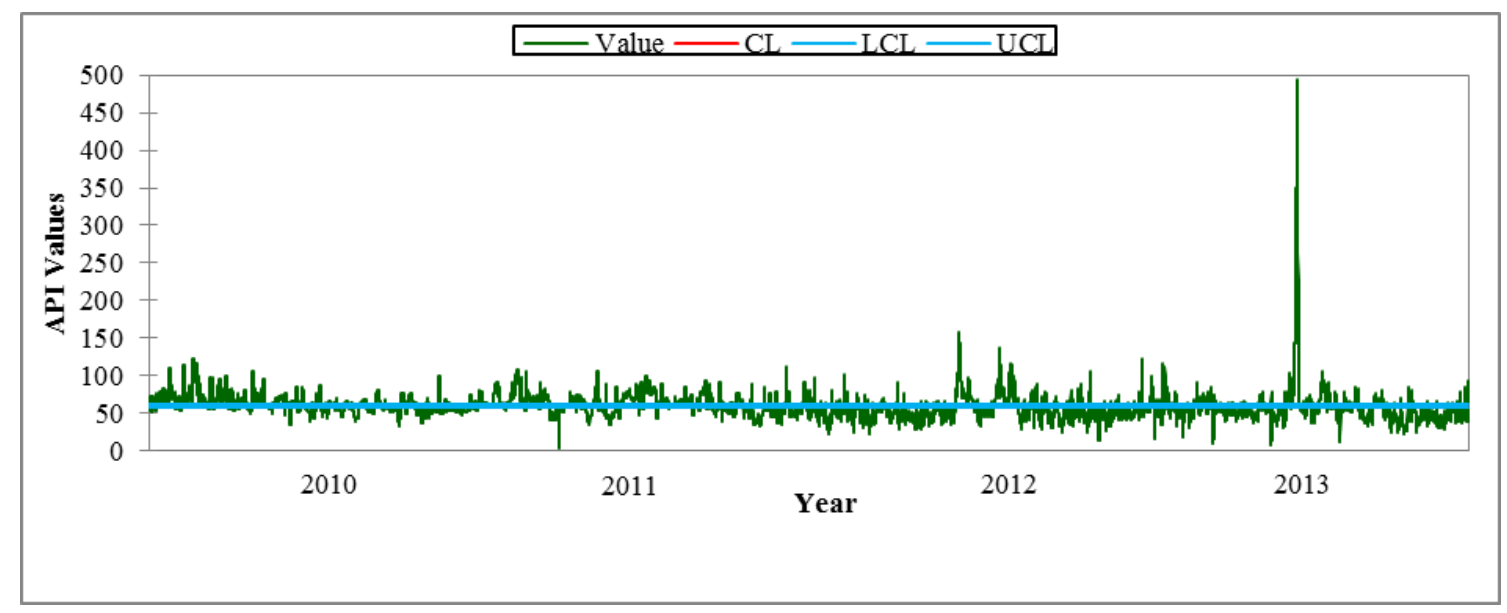

Fig.6. API individual chart

The patterns for $\mathrm{NO}_{2}, \mathrm{CO}$ and $\mathrm{PM}_{10}$ shown remarkable decreased between 2011 and 2012. There was a sudden reduction in the number of project development in Selangor from 2,232 projects (2011) to 1, 865 projects (2012), as the DOE started to implement strict guidelines for the application of project development [20]. Besides that, prevention of open burning at fires prone areas was executed in March 2010 in compliance to the Environmental Quality (Declared Activities) (Open Burning) Order in 2003 to reduce air pollution from domestic sources [18-19]. There were 14 signage on the open burning prohibition had been set up around Johan 
Setia, Klang by 2012 in order to increase public's awareness on peatland fires [18]. Furthermore, construction of check dams to stop peatland from drying up during hot weather, also effective in preventing peatland fires in Klang [18].

This study indicated that transboundary haze pollution had been affecting air quality in Klang, Selangor. This is also a long-standing problem in the South East Asia since 1997. Many resolutions had been implemented in order to keep Asian free from haze, which include ASEAN Agreement on Transboundary Haze Pollution 2002 (AATHP) and ASEAN Peatland Management Strategy 2006-2020 (APMS) [22-23]. Latest study by revealed although AATHP was lacking in enforceable mandatory provisions, it remains beneficial tool for regional collaboration in combatting transboundary pollution. Besides, active participation and cooperation among publics and private sectors also play a major role in this issue [24].

Eleventh Malaysia Plan 2016-2020 on air quality emphasized on low carbon mobility by encouraging the use of energy efficient vehicles (EEVs), increase biofuels and compressed natural gas (CNG) usage, place higher fuel standards and increase the use of public transportations. These plans were aiming to reduce emission of gases and to promote green growth for sustainability development [25]. Based on the information above, mitigation measures on controlling air pollution in Klang have been taken earnestly by the local authority, state government of Selangor and Malaysia government as well as international bodies in ensuring good air quality status.

\section{CONCLUSION}

From this study, it could be concluded that there was a significant association in the air quality data in Klang. All air pollutants were significantly positive correlated with each other. CO and $\mathrm{NO}_{2}$ had a strong correlation due to the high emission of motor vehicles. API level in Klang was significantly more correlated with $\mathrm{PM}_{10}$ compared to other variables. PCA analysis indicated that $\mathrm{NO}_{2}, \mathrm{CO}$ and $\mathrm{PM}_{10}$ were the most significant air pollutants that contributed to the air pollution in Klang. The sources of these pollutants were mainly from emission of transportation, industrial activities, domestic open burning and transboundary haze pollution. Overall, all air pollutants level were in compliance to the RMAQG, except for $\mathrm{PM}_{10}$ due to several haze episodes of transboudary pollution from Indonesia and peatland fires in Klang. 
This study also revealed that the API pattern [26-27] in Klang was mainly similar to the pattern of $\mathrm{PM}_{10}$ and $\mathrm{CO}$. Thus, active collaboration among all environmental departments and agencies is necessary for the effective management of air quality in order to have a cleaner and healthier environment in the future.

\section{ACKNOWLEDGEMENTS}

I would like to take this opportunity to express my sincere gratitude and appreciations to my supervisor, Dr Ahmad Shakir Mohd Saudi of Universiti Kuala Lumpur, Institute of Medical Science and Technology (UniKL MESTECH) for his great efforts, supervision and guidance throughout this research. A special thanks to the Malaysian Department of Environment (DOE) in providing useful secondary air quality database for Klang, Selangor. Last but not least, my deepest thanks to my family and friends for their endless supports and advices in completing this research.

\section{REFERENCES}

[1] Makmom A A, Armi A S M, Yee J T. An overview of the air pollution trend in Klang Valley, Malaysia. Open Environmental Sciences, 2012, 6(1):13-19

[2] Rahman SR, Ismail SN, Raml MF, Latif MT, Abidin EZ, Praveena SM. The assessment of ambient air pollution trend in Klang Valley, Malaysia. World Environment, 2015, 5(1):1-11

[3] Department of Environment (DOE) Malaysia. Chronology of haze episodes in Malaysia. Putrajaya: DOE, 2016

[4] Azid A, Juahir H, Toriman ME, Endut A, Kamarudin MK, Rahman MN, Hasnam CN, Saudi AS, Yunus K. Source apportionment of air pollution: A case study in Malaysia. Jurnal Teknologi, 2015, 72(1):83-88

[5] Amran MA, Azid A, Juahir H, Toriman ME, Mustafa AD, Hasnam CN, Azaman F, Kamarudin MK, Saudi AS, Yunus K. Spatial analysis of the certain air pollutants using environmetric techniques. Jurnal Teknologi, 2015, 75(1):241-249

[6] Isiyaka HA, Juahir H, Toriman ME, Azid A, Gasim BM, Kamarudin MK. Assessment of the spatial variation and source apportionment of air pollution based on chemometric techniques: A case study in the Peninsular Malaysia. Jurnal Teknologi, 2015, 77(1):33-44 
[7] Kovač-Andrić E, Radanović T, Topalović I, Marković B, Sakač N. Temporal variations in concentrations of ozone, nitrogen dioxide, and carbon monoxide at Osijek, Croatia. Advances in Meteorology, 2013, 2013:1-7

[8] Azmi SZ, Latif MT, Ismail AS, Juneng L, Jemain AA. Trend and status of air quality at three different monitoring stations in the Klang Valley, Malaysia. Air Quality, Atmosphere and Health, 2010, 3(1):53-64

[9] Dominick D, Juahir H, Latif MT, Zain SM, Aris AZ. Spatial assessment of air quality patterns in Malaysia using multivariate analysis. Atmospheric Environment, 2012, 60:172-181 [10] Jamalani MA, Abdullah AM, Azid A, Ramli MF, Baharudin MR, Bose MM, Elhadi RE, Youssef KA, Gnadimzadeh A, Gumel DY. Monthly analysis of $\mathrm{PM}_{10}$ in ambient air of Klang Valley, Malaysia. Malaysian Journal of Analytical Sciences, 2016, 20(5):1159-1170

[11] Prati MV, Costagliola MA, Quaranta F, Murena F. Assessment of ambient air quality in the port of Naples. Journal of the Air and Waste Management Association, 2015, 65(8):970-979

[12] AhmadIsiyaka H, Juahir H, Toriman ME, Gasim BM, Azid A, Amri MK, Ibrahim A, Usman UN, Rano AR, Garba MA. Spatial assessment of air pollution index using environ metric modeling techniques. Advances in Environmental Biology, 2014, 8(24):244-256

[13] Ministry of Transport Malaysia (MOT). Transport statistic Malaysia 2015. Putrajaya: MOT, 2015

[14] Islam MS, Hui Pei Y, Mangharam S. Trans-boundary haze pollution in Southeast Asia: Sustainability through plural environmental governance. Sustainability, 2016, 8(5):1-13

[15] Sunchindah A. Transboundary haze pollution problem in Southeast Asia: Reframing ASEAN's response. 2015, http://www.eria.org/ERIA-DP-2015-59.pdf

[16] Mohamad ND, Ash'aari ZH, Othman M. Preliminary assessment of air pollutant sources identification at selected monitoring stations in Klang Valley, Malaysia. Procedia Environmental Sciences, 2015, 30:121-126

[17] Department of Environment (DOE) Malaysia. Malaysia environmental quality report 2012. Putrajaya: Ministry of Natural Resources and Environment, 2012

[18] Department of Environment (DOE) Malaysia. Malaysia environmental quality report 2013. Putrajaya: Ministry of Natural Resources and Environment, 2013 
[19] Department of Environment (DOE) Malaysia. Malaysia environmental quality report 2010. Putrajaya: Ministry of Natural Resources and Environment, 2010

[20] Department of Environment (DOE) Malaysia. Environment quality report. Putrajaya: Ministry of Natural Resources and Environment

[21] Ling Hoon Leh O, Musthafa SN, Mohamed N. Air quality and land use in urban region of Petaling Jaya, Shah Alam and Klang, Malaysia. EnvironmentAsia, 2014, 7(1):134-144

[22] Association of Southeast Asian Nations (ASEAN). Asean Programme on Sustainable Management of Peatland Ecosystems 2014-2020 (APSMPE). 2016, http://environment.asean.org/wp-content/uploads/2016/11/APSMPE-flyer.pdf

[23] Association of Southeast Asian Nations (ASEAN). Roadmap on ASEAN cooperation towards transboundary haze pollution control with means of implementation. 2016, http://environment.asean.org/wp-content/uploads/2016/11/Roadmap-ASEAN-Haze-Free_ado ptedbyCOP12.pdf

[24] Nazeer N, Furuoka F. Overview of ASEAN environment, transboundary haze pollution agreement and public health. International Journal of Asia-Pacific Studies, 2017, 13(1):73-94 [25] Economic Planning Unit (EPU). Eleventh Malaysia Plan-Chapter 6: Pursuing green growth for sustainability and resilience. Putrajaya: Prime Minister's Department, 2015

[26] Kamarudin MK, Nalado AM, Kasmuri A, Toriman ME, Juahir H, Umar R, Jamil NR, Saudi AS, Rizman ZI, Gasim MB, Hassan AR. Assessment of river plan changes in Terengganu River using RS and GIS method. Journal of Fundamental and Applied Sciences, $2017,9(2 S): 28-45$

[27] Saudi AS, Kamarudin MK, Ridzuan IS, Ishak R, Azid A, Rizman ZI. Flood risk index pattern assessment: Case study in Langat River basin. Journal of Fundamental and Applied Sciences, 2017, 9(2S):12-27

\section{How to cite this article:}

Shafii N Z, Saudi A S M, Mahmud M, Rizman Z I. Spatial assessment on ambient air quality status: a case study in klang, selangor. J. Fundam. Appl. Sci., 2017, 9(4S), 964-977 